\title{
Anthós
}

\section{Embedding Parallel Computation in a Stochastic Mesh Network: A Morphogenetic Approach}

Max Orhai

Portland State University

Follow this and additional works at: https://pdxscholar.library.pdx.edu/anthos

Part of the Computer Sciences Commons

Let us know how access to this document benefits you.

\section{Recommended Citation}

Orhai, Max (2011) "Embedding Parallel Computation in a Stochastic Mesh Network: A Morphogenetic Approach," Anthós: Vol. 3: Iss. 1, Article 3.

https://doi.org/10.15760/anthos.2011.22

This open access Article is distributed under the terms of the Creative Commons Attribution-NonCommercialShareAlike 4.0 International License (CC BY-NC-SA 4.0). All documents in PDXScholar should meet accessibility standards. If we can make this document more accessible to you, contact our team. 
embedding parallel computation in a stochastic mesh network: a morphogenetic approach

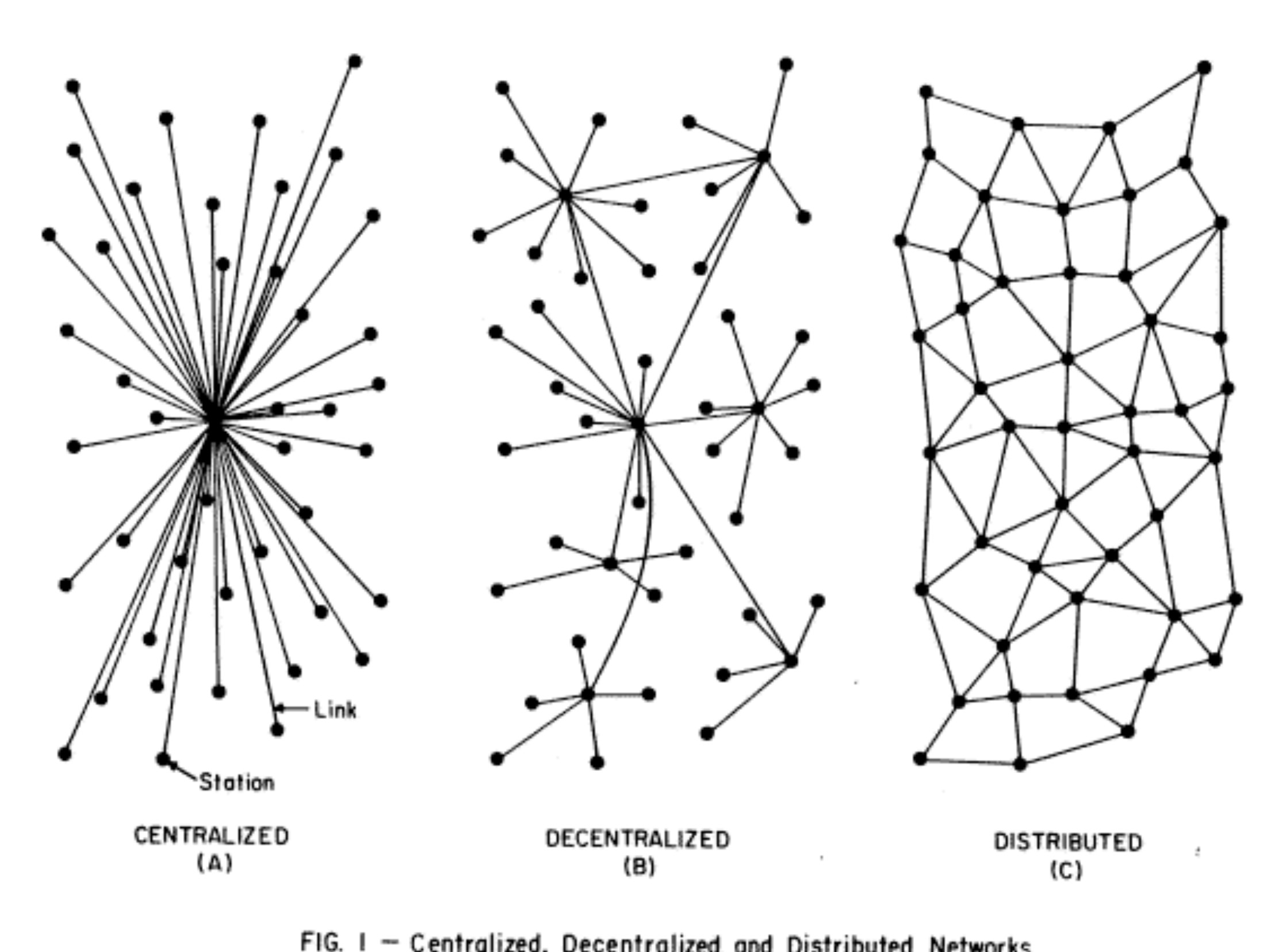

Many basic techniques in computer science have been founded on the assumption
that physical computing resources are scarce but orderly and that the cost of that physical computing resources are scarce but orderly, and hat the cost of system is affordable. In ubiquitous computing systems such as sensor networks,
or in the design of nano-scale systems, these familiar assumptions may not hold. What if we suppose instead that computing capacity is plentiful, but that only local communication is possible, and the exact structure of the communication
network . How can we program a locally connected network of randomly placed computing nodes to do a practical computiting task, whil
parallel processing capacity of the network?

We believe that the organization and dynamics of biological processes may conditions. This algorithm a variation hardware and software under these new abstract model of morphogenentic cell sorting in the development of multicellular
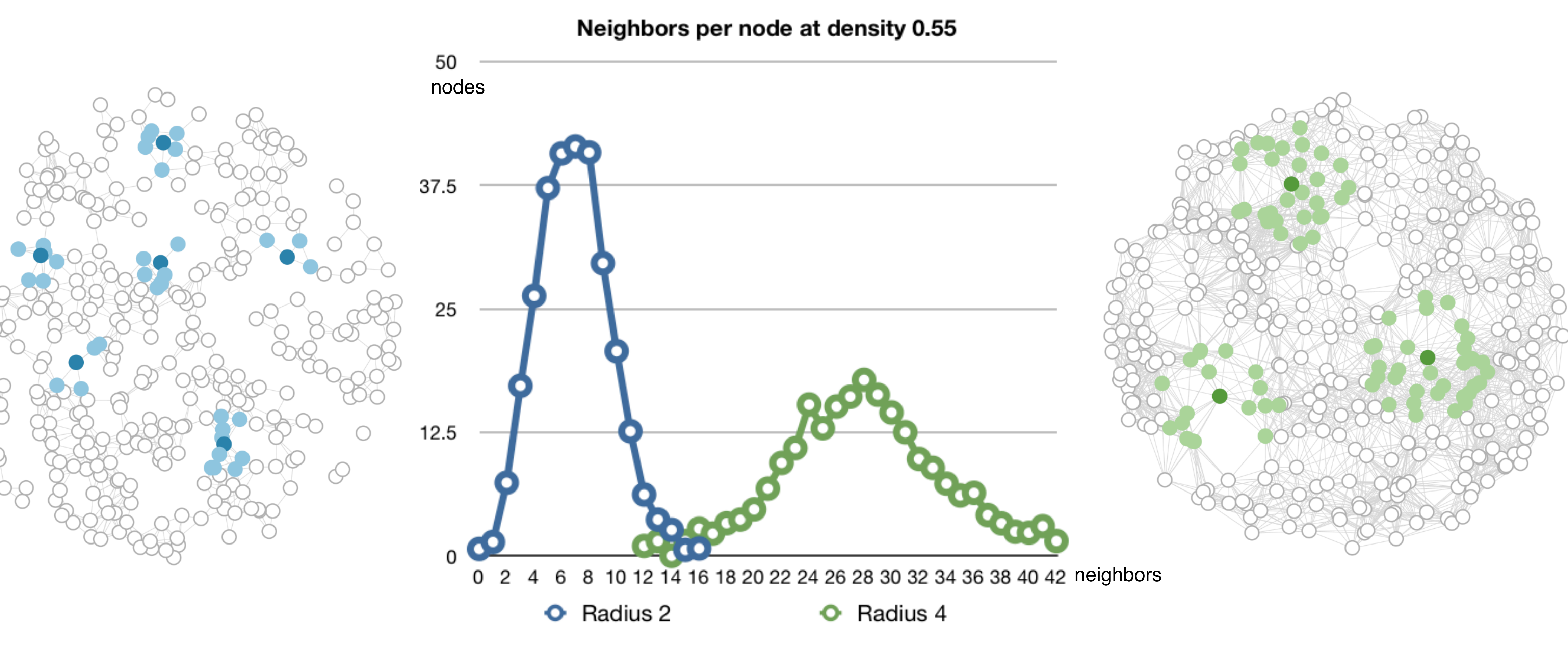

Each node has a spatial neighborhood which determines which other nodes it may communicate with. The size of these neighborhoods determines the

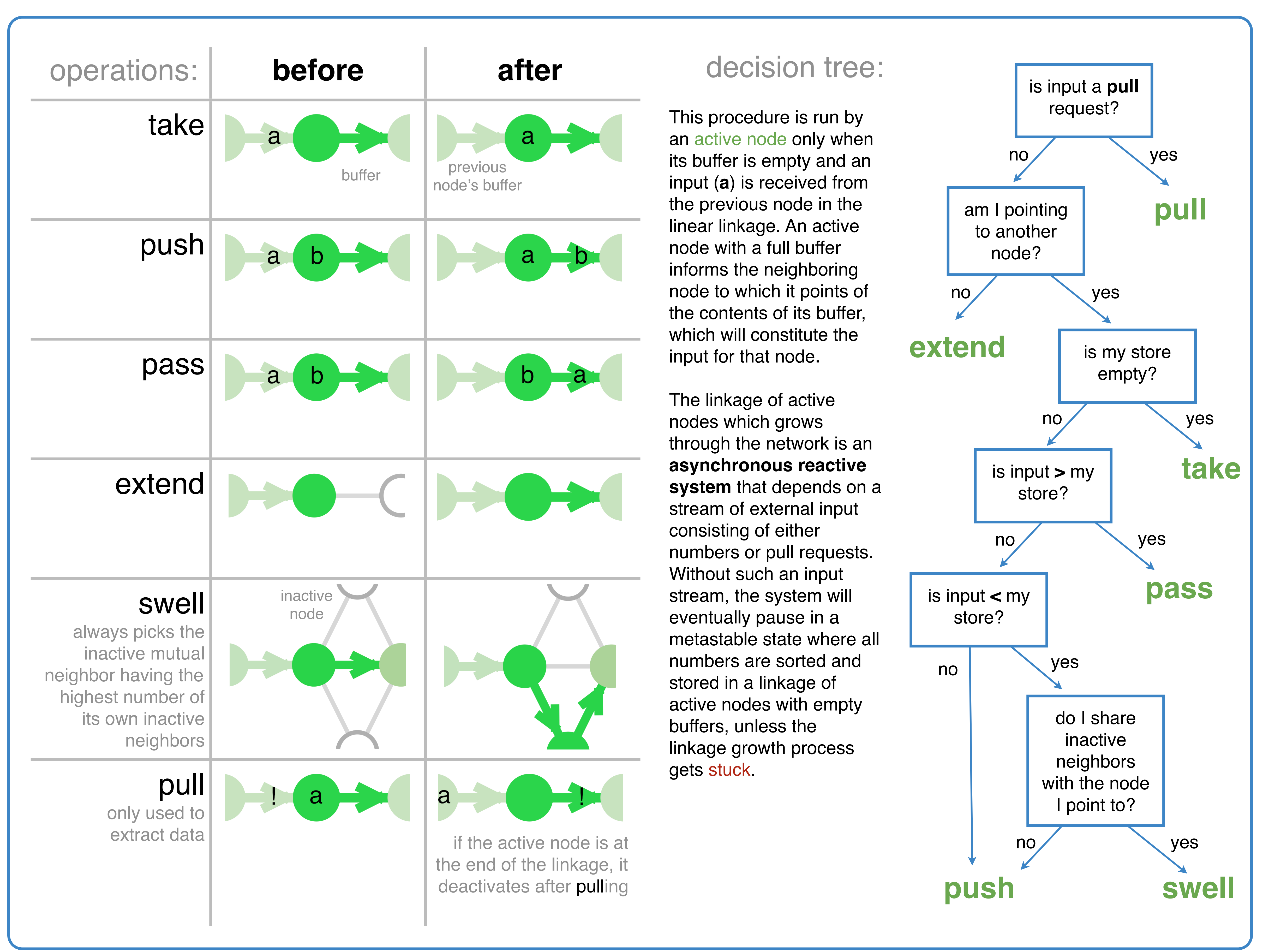

The sequence of images below shows the algorithm in dyhamic linear linkage active dala structure is $g$ iow which sorts the numbers in parallel as a length-
conserving and dead-end-avoiding path is found.
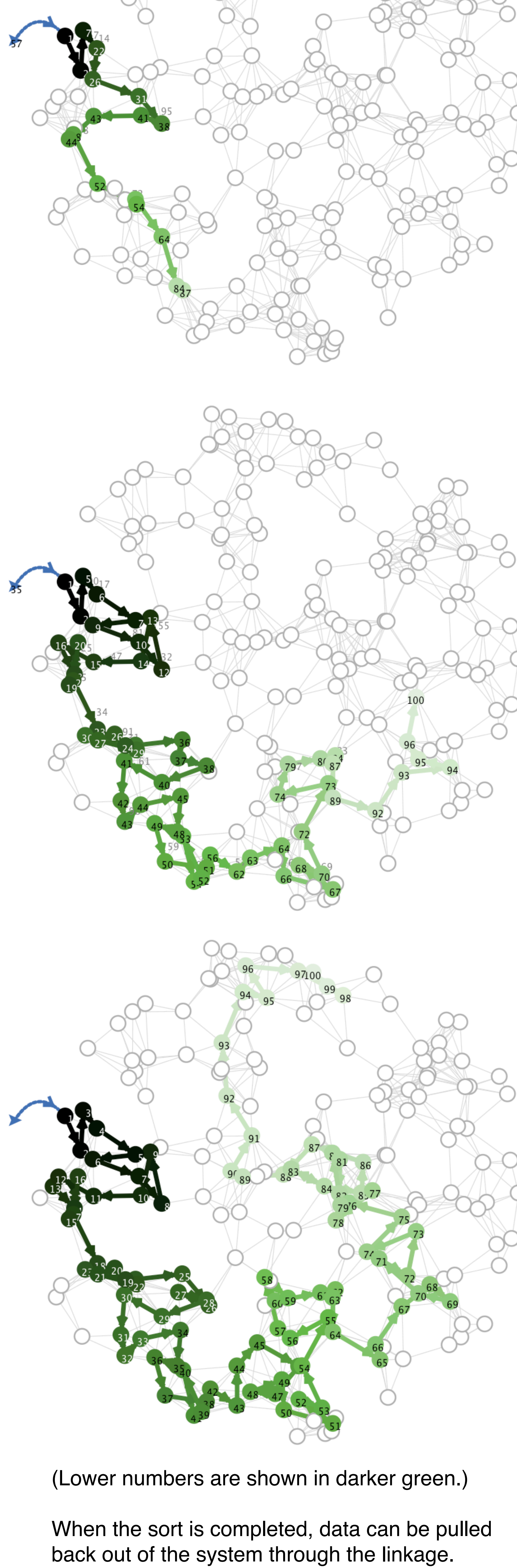
龟 Portland State
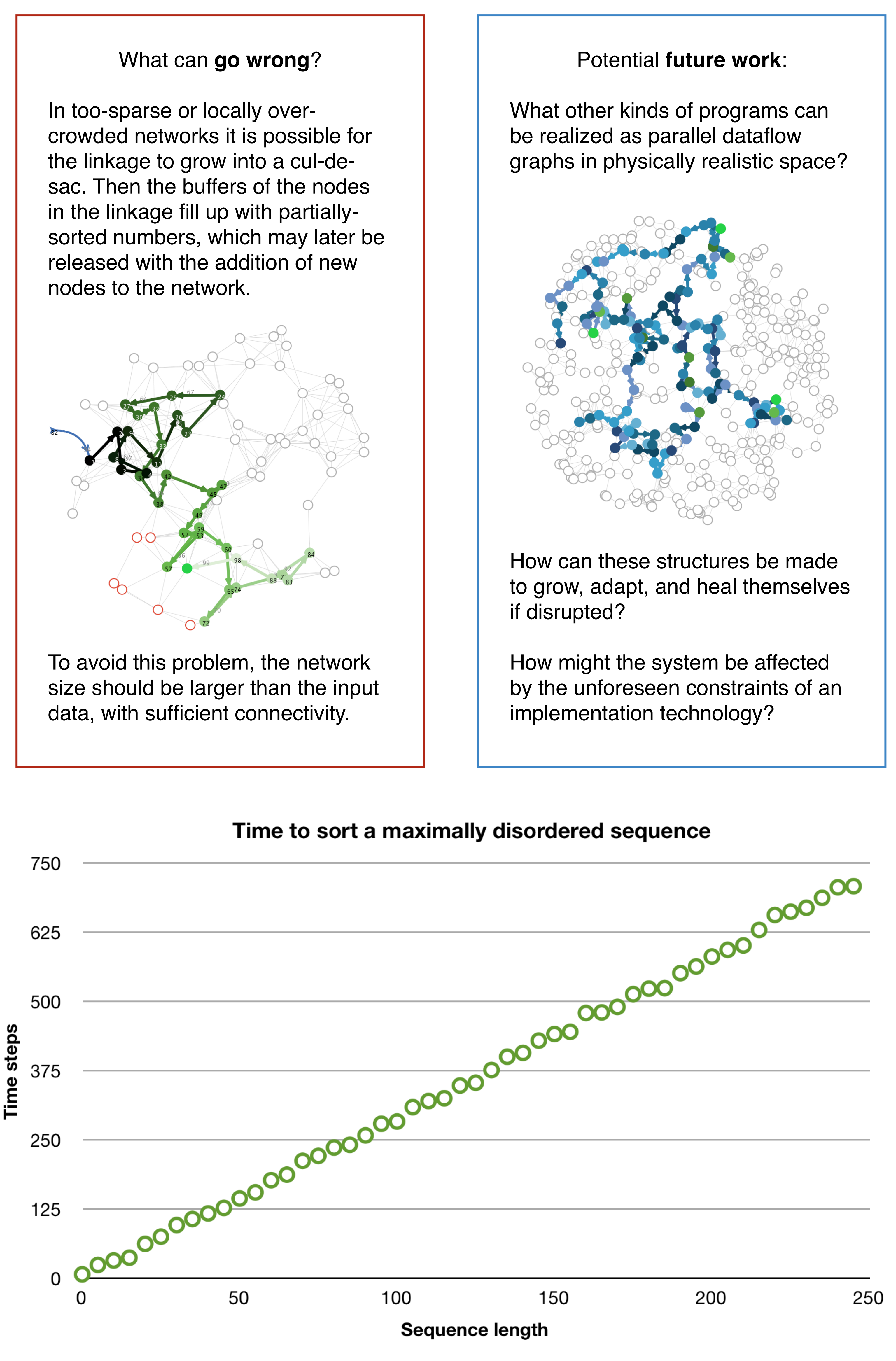

The chart above shows the performance of the parallel insertion sort. In a sequential computer, this algorithm takes we are able to complete the task in linear timet

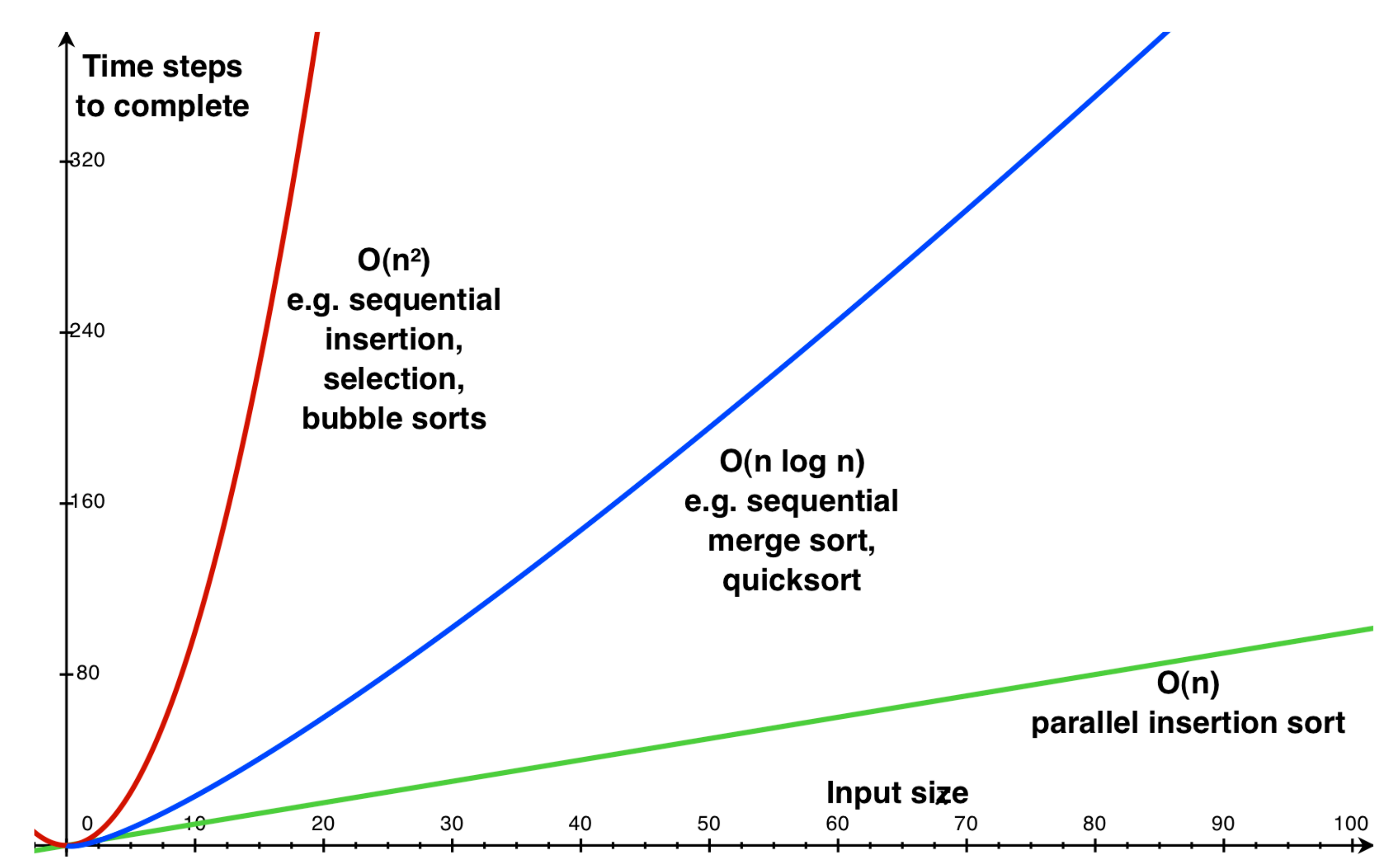

References and related work:

Jacob Beal and Gerald Sussman. Biologically-Inspired Robust Spatial Programming. MIT

Neil Gershenfeld, David Dalrymple, Kailiang Chen, Ara Knaian, Forrest Green, Erik D. Demaine, Sroceedings of the ACM Conferenc- on Principles of Programming Languages Logic Automat 2010 . Robert Rosen. Morphogenesis in Networks. Chapter in Essays on Life Itself, Columbia 